\title{
POLITIK HUKUM PENGENDALIAN TENAGA KERJA ASING YANG BEKERJA DI INDONESIA
}

\author{
Anis Tiana Pottag \\ tiana.pottag@gmail.com \\ Universitas Airlangga
}

\begin{abstract}
The inception of the regulation No. 6 year concerning immigration 2011 and No. 13 year 2003 and regarding the employment has had a huge impact in the political direction of the law controlling foreign workers who works in Indonesia. The controlling system of foreign workers who work in Indonesia aims to protect the rights of Indonesian citizens from losing their jobs because of the high number of foreign workers who come to work in Indonesia. As the implementation of an Article 27 paragraph 2 of the national constitution in 1945 specifies where every citizen of Indonesia has the right to work and a decent subsistence for humanity. As the state which constituted by the law, Indonesia has a responsibility to protect the rights of its citizens in accordance with Article number 28, paragraph 4 where the protection, promotion, enforcement and fulfilment of human rights is the responsibility of the state, especially in this case is the responsibility of the government. The utilization of foreign labor in Indonesia should be limited in number and areas that can be occupied by the foreign labor. The Labor law and regulation limit the positions that can be occupied by the foreign labor. The positions which are prohibited (closed list) should be considered by the employer before filing the utilization of foreign labor. Apart from having to comply with the provisions regarding the positions, the employer should also pay attention to the standards of an applicable competency.
\end{abstract}

Keywords: Political Law; Foreign Labor, Employment Regulation.

\begin{abstract}
Abstrak
Lahirnya undang-undang No. 6 Tahun 2011 tentang Keimigrasian dan Undang-undang No. 13 tahun 2003 tentang Ketenagakerjaan telah membawa dampak besar dalam arah politik hukum pengendalian tenaga kerja asing yang bekerja di Indonesia . Pegendalian tenaga kerja asing yang bekerja di Indonesia bertujuan untuk melindungi hak warga negara Indonesia dari kehilangan pekerjaannya dikarenakan banyaknya tenaga kerja asing yang datang untuk bekerja di Indonesia. Sebagai implementasi dari Pasal 27 ayat 2 UUD 1945 menjelaskan dimana tiap-tiap warga negara berhak atas pekerjaan dan penghidupan yang layak bagi kemanusiaan. Sebagai negara hukum, negara Indonesia mempunyai kewajiban untuk melindungi hak warga negaranya sesuai dengan Pasal 28 I ayat 4 dimana Perlindungan, pemajuan, penegakan, dan pemenuhan hak asasi manusia adalah tanggung jawab negara, terutama pemerintah. Penggunaan tenaga kerja asing di Indonesia harus dibatasi baik dalam jumlah maupun bidang-bidang yang dapat diduduki oleh tenaga kerja asing. Undang-undang Ketenagakerjaan membatasi jabatan-jabatan yang dapat diduduki oleh tenaga kerja asing. Jabatan-jabatan yang dilarang (closed list) ini harus diperhatikan oleh si pemberi kerja sebelum mengajukan penggunaan tenaga kerja asing. Selain harus mentaati ketentuan tentang jabatan, juga harus memperhatikan standar kompetansi yang berlaku.
\end{abstract}

Kata Kunci: Politik Hukum; Tenaga Kerja Asing; Hukum Ketenagakerjaan.

\section{Pendahuluan}

Era Globalisasi saat ini telah mempengaruhi perekonomian dunia dalam pranata yang sangat luas, era globalisasi juga menuntut ASEAN menciptakan 
integrasi secara menyeluruh di kawasan Asia Tenggara. Integrasi ini di Asia Tenggara ini disebut dengan ASEAN VISION 2020. Unsur utama dari ASEAN Vision 2020 salah satunya adalah keberadaan ASEAN Economic Community 20015 atau disebut dengan Masyarakat Ekonomi ASEAN 2015 (selanjutnya disebut MEA). ${ }^{1}$

Deklarasi $A S E A N$ yang di nyatakan di Singapura diantaranya sepuluh negara $A S E A N$ telah bersepakat untuk saling menandatangani kesepakatan MEA. MEA tersebut telah disepakati beberapa elemen penting yaitu kurang lebih ada lima dalam integrase perekonomian $A S E A N$ diantaranya adalah liberalisme arus tenaga kerja dari berbagai negara. Liberalisasi tenaga kerja terjadi karena adanya pembebasan arus tenaga kerja ahli terbatas sampai tahun 2020 sebagai dampak adanya MEA, selebihnya keseluruhan tenaga kerja bisa melakukan migrasi dengan bebas dengan tidak membutuhkan visa kerja khusus dan perizinan yang menyulitkan banyak tenaga kerja dari negara berkembang di ASEAN khususnya.

Pengawasan terhadap Orang Asing berkainan dengan adanya MEA juga perlu lebih ditingkatkan sejalan dengan meningkatnya kejahatan internasional dan tindak pidana transnasional, diantaranya perdagangan orang, Penyelundupan Manusia, dan tindak pidana lainnya yang berkaitan narkotika yang banyak dilakukan oleh sindikat kejahatan internasional yang terorganisasi dan profesional. Pengawasan terhadap Orang Asing tidak cukup hanya dilakukan pada saat mereka masuk saja, tetapi juga selama mereka berada di Wilayah Negara Republik Indonesia, termasuk kegiatan dan tikah lakunya. Pengawasan Keimigrasian mencakup penegakan hukum di bidang Keimigrasian, baik yang bersifat administratif maupun tindak pidana Keimigrasian pada umumnya.

Hadirnya Tenaga Kerja Asing (selanjutnya disebut TKA) di negara Indonesia akan berdampak bagi pendapatan asli daerah (selanjutnya disebut PAD). Sampai saat ini terlihat jelas dengan belum banyak daerah yang memiliki Peraturan Daerah tentang Retribusi Perpanjangan Izin Mempekerjakan Tenaga Kerja Asing

\footnotetext{
${ }^{1}$ Budi S.P. Nababan, 'Pembentukan Peraturan Daerah Tentang Retribusi Perpanjangan Izin Mempekerjakan Tenaga Kerja Asing Sebagai Persiapan Menghadapi Masyarakat Ekonomi ASEAN 2015' (2014) 3 Rechvinding.[174].
} 
(selanjutnya disebut dengan Perda Retribusi Perpanjangan IMTA) sebagai dasar hukum dalam pemungutan retribusi perpanjangan terhadap IMTA.

Perkembangan teknologi di segala bidang kehidupan, baik meliputi bidang transportasi, informasi, dan ekonomi, mengakibatkan batas-batas negara semakin menipis dan aktifitas orang masuk dalam dan keluar wilayah negara Indonesia akan semakin besar dan semakin sulit untuk di bendung. Semakin banyak orang asing yang masuk serta berada di Indonesia dengan berbagai macam kepentingannya, maka aktifitas tersebut dapat mengakibatkan seseorang untuk menikah walaupun mereka memiliki perbedaan kewarganegaraan. ${ }^{2}$

Permasalahan yang timbul adalah bahwa jumlah TKA yang bekerja di Indonesia semakin meningkat, dampak hukum dari permasalahan tersebut berupa semakin meningkatnya pelanggaran terhadap berbagai macam peraturan perundangundangan tentang keimigrasian, dimana banyak orang asing yang lalai atau dengan sengaja tidak melakukan pelaporan dalam menjalankan kewajibannya sebagaimana dimaksud dalam pasal 71 huruf a Undang-undang No. 6 Tahun 2011 tentang keimigrasian, yaitu kewajiban orang asing untuk memberikan segala keterangan menyangkut identitas dirinya dan keluarganya serta melaporkan setap perubahan status sipil, kewarganegaraan, pekerjaan, penjamin, atau perubahan alamatnya kepada kantor imigrasi setempat. Dampak lainnya secara ekonomi, kehadiran TKA bias jadi menutup peluang pekerjaan bagi WNI dalam memperoleh jabatan-jabatan strategis disuatu perusahaan tertentu.

Sebagai negara hukum (rechtstaat) tentunya yang menjadi salah satu kewajiban bagi negara Indonesia untuk memberikan kepastian hukum terhadap TKA yang bekerja di Indonesia. Kebutuhan TKA di Indinesia tidak menutup kemungkinan bahwa semakin hari TKA semakin banyak di Indinesia oleh karena itu diperlukan Kepastian hukum itu tidak cukup pada hanya satu lembaga saja, melainkan melibatkan lembaga lain. Dalam hal ini selain Kementerian Tenaga Kerja, juga melibatkan Kementerian Hukum dan HAM (Hak Asasi Manusia) dan juga Keimigrasian .

\footnotetext{
${ }^{2}$ Jazim Hamidi dan Charles Christian, Hukum Keimigrasian Bagi Orang Asing Di Indonesia (Sinar Grafika 2015).[10].
} 
Masuknya TKA ke Indonesia selain peluang tercipta karena peraturan yang positifjuga dikarenakan dikalangan masyarakat kita, khususnya pengusaha biasanya lebih memilih menggunakan TKA untuk bekerja. Sehingga semakin banyaknya TKA yang masuk ke Indonesia. Interaksi TKA dengan WNI menimbulkan komunikasi dan menyebabkan akan saling dekatnya hubungan yang timbul antara mereka. Terjadinya interaksi antara TKA tersebut dengan masyarakat sering kali terjadi hubungan yang lebih serius dikarenakan adanya faktor saling membutuhkan sehingga terbentuknya ikatan sosial yang erat dan berlanjut ke jenjang yang lebih serius yakni perkawinanan. Semakin banyaknya perkawinan campuran yang terjadi di Indonesia merupakan salah satu dampak dari masuknya TKA ke Indonesia. Perkawinan campuran antara WNI dengan WNA tersebut maka selain melibatkan dua lembaga di atas yang telah disebutkan yaitu Ketenagakerjaan dan Keimigrasian juga melibatkan beberapa lembaga perkawinan.

Permasalahan izin tinggal di bidang keimigrasian sesuai dengan UU No. 6 Tahun 2011 tentang keimigrasian, dalam Pasal 52 huruf e Dan dalam Pasal 54 ayat 1 huruf $b$. Tersirat juga dalam pasal 61 disebutkan bahwa pemegang izin tinggal terbatas sebagaimana dimaksud dalam pasal 52 huruf e dan $\mathrm{f}$ dan pemegang izin tinggal tetap sebagaimana dimaksud dalam pasal 54 ayat 1 huruf $b$ dan huruf $d$ dapat melakukan pekerjaan dan / atau usaha untuk memenuhi kebutuhan hidup dan /atau keluarganya. Pasal ini sebelumnya UU No. 9 Tahun 1992 tentang keimigrasian tidak memberikan kesempatan bekerja kepada orang asing atas sponsios sitrinya atau suaminya untuk bekerja di Indonesia namun dengan UU No. 6 Tahun 2011 tentang keimigrasian memberikan kesempatan kepada orang asing yang mendapatkan sponsor istri atau suami WNI untuk bekerja di Indonesia. Munculnya pasal ini merupan suatu bentuk dari penghormatan terhadap HAM dalam rangka bekerja untuk memenuhi kehidupan yang layak.

UU No. 13 tahun 2003 tentang ketenagakerjaan telah menyebutkan pengaturan tentang bagaimana tata cara menggunakan TKA terdapat pada pasal 42 sampai 49, yang menentukan bahwa suatu kewajiban pemberi kerja yang menggunakan TKA untuk dapat memperoleh izin tertulis, jenis jabatan, memiliki rencana penggunaan TKA yang 
memuat alasan, serta jangka waktu penggunaan TKA, suatu kewajiban terhadap TKI sebagai pendamping TKA hingga kewajiban mengembalikan TKA kenegara asalnya setelah bemasa hubungan kerja berakhir. Hukum ketenagakerjaan ternyata masih memberi batasan-batasan terhadap penggunaan TKA di Indonesia, setiap pengajuan dan rencana penggunaan TKA di Indonesia masih dibatasi baik dalam jumlah maupun bidang-bidang pekerjaan apa saja yang dapat diduduki oleh TKA.

UU No. 6 Tahun 2011 tentang Keimigrasian menimbulkan dampak secara hukum, pertentangan secara normatif dari beberapa peraturan terkait serta politik hukum ketenagakerjaan dan politik hukum keimigrasian itu sendiri. Selain itu juga menimbulkan beberapa ketidakpastian hukum bagi WNA yang telah menikah dengan WNI, karena menurut keimigrasian mereka telah diperbolehkan untuk bekerja, namun menurut ketenagakerjaan mereka tidak boleh bekerja tanpa mendapatkan izin dari Kemerinterian Tenaga Kerja dan Transmigrasi. Berlakunya UU No. 6 tahun 2011 tentang Keimigrasian, di khawatrikan menimbulkan masalah baru yakni aka nada banyaknya perkawinan kontrak antara WNA dan WNI demi mendapatkan kebebasan bagi WNA dalam mendapatkan izin tinggal serta bekerja di Indonesia. ${ }^{3}$

Berdasarkan urain tersebut diatas maka akan di bahas lebih lanjut mengenai Politik hukum pengendalian tenaga kerja asing yang berkerja di Indonesia, yang meliputi tentang ratio legis pengendalian tenaga kerja asing, Politik hukum pengaturan orang asing di Indonesia serta pengawasan orang asing yang berada di Indonesia. Tipe penelitian yang digunakan dalam tulisan ini adalah Doctrinal Research, ${ }^{4}$ dimana dimulai dengan mengumpulkan norma hukum dari sumbernya, menganalisis hubungan antar norma hukum, menjelaskan bidang-bidang yang sulit, dan memberikan prediksi mengenai perkembangan ke depan (futuristic) tentang norma-norma hukum tersebut di bagian kesimpulan tulisan. Norma-norma hukum tersebut dapat ditemui dalam peraturan perundang-undangan khususnya dalam hal yang berkaitan dengan Politik Hukum, Perizinan, Perlindungan Hukum serta ilmu perundang-undangan.

${ }^{3}$ Charles Christian, Hukum Keimigrasian Bagi Orang Asing Di Indonesia (Sinar Grafika 2015).[16].

${ }^{4}$ Peter Mamud Marzuki, Penelitian Hukum (Kencana 2006).[32-33]. 


\section{Ratio Legis Pengendalian Tenga Kerja Asing Yang Bekerja Di Indonesia}

Pasal 1 ayat 3 Undang-Undang Dasar Negara Kesatuan Republik Indonesia Tahun 1945 menyebutkan, bahwa "Negara Indonesia negara hukum". Negara hukum dimaksud adalah negara yang menegakan supermasi hukum untuk menegakan kebenaran dan keadilan dan tidak ada kekuasaan yang tidak dipertanggungjawabkan. ${ }^{5}$ Menurut Philipus M. Hadjon, ${ }^{6}$ baik konsep "the rule of law" maupun konsep "rechtsstaat" menempatkan pengakuan dan perlindungan terhadap hak-hak asasi manusia sebagai titik sentral. Untuk melindungi hak-hak asasi manusia dalam konsep "the rule of law" mengedepankan prinsip "equality before the law" dan dalam konsep "rechtstaat" mengedepankan prinsip “wetmatigheid” kemudian menjadi "rechtmatigheid”. Politik hukum berbicara tentang apa yang seharusnya, yang tidak selamanya identik dengan apa yang ada. Politik hukum tidak bersifat pasif terhadap apa yang ada, melainkan aktif mencari apa yang seharusnya. Karena politik hukum adalah menyangkut cita-cita atau harapan, maka harus ada visi terlebih dahulu, dan dalam jalur visi terlebih dahulu, dan dalam jalur visi itulah bentuk da nisi hukum dirancang-bangun untuk mewujudkan visi tersebut. ${ }^{7}$

Menurut Mahfud MD, politik hukum adalah legal policy yang akan atau telah dilaksanakan secara nasional oleh Pemerintah Indonesia yang meliputi : Pertama, pembangunan hukum yang berintikan pembuatan dan pembaharuan terhadap materimateri hukum agar dapat sesuai dengan kebutuhan; kedua, pelaksanaan ketentuan hukum yang telah ada termasuk penegasan fungsi lembaga dan pembinaan para penegak hukum. Dari pengertian tersebut terlihat politik hukum mencakup proses pembuatan dan pelaksanaan hukum yang dapat menunjukkan sifat dan ke arah mana hukum akan di bangun dan di tegakkan. ${ }^{8}$

\footnotetext{
${ }^{5}$ Panduan Pemasyarakatan Undang-Undang Dasar Republik Indonesia Tahun 1945 (Sesuai dengnan Urutan Bab, Pasal dan ayat) 2010.[46].

${ }^{6}$ Philipus M. Hadjon, Pengantar Hukum Admistrasi Indonesia (Gadjah Mada University Press 2008).[79-80].

${ }^{7}$ Bernard L, Politik Hukum (Genta Publising 2011).[3].

${ }^{8}$ Mahfud MD, Politik Hukum Di Indonesia, (Rajawali Pers 2010).[17].
} 
Undang-Undang Keimigrasian menyebutkan bahwa perlindungan hukum diberikan baik kepada WNI ataupun WNA yang berada di Indonesia. Kepada WNI dapat dilihat bahwa setiap WNI berhak melakukan perjalanan keluar negeri dan oleh karenanya untuk memberikan jaminan perlindungan hukum, Pemerintah melalui Institusi Imigrasi memberikan paspor atau surat perjalanan yang memuat identitas pemegangnya. Dengan demikian, bahwa setiap pemegang paspor tersebut di manapun keberadaannya tetap mendapatkan perlindungan hukum dari negara Indonesia.

Pemerintah Indonesia menginginkan agar kehadiran TKA membawa dampak positif dalam pemberian devisa, ahli teknologi, dan meningkatkan daya saing yang menimbulkan motivasi bagi TKI untuk lebih mengembangkan diri sehingga memiliki daya saing yang tinggi. Oleh karenanya politik hukum keimigrasian dalam hal pemberian Ijin tinggal misalnya, dapat dikatakan bahwa berdasarkan pada asas manfaat secara perekonomian dan Asas kesetaraan gender bagi mereka yang memperoleh Ijin tinggal karena pernikahan campuran. Selain hal diatas Asas Penghormatan terhadap HAM juga dapat dilihat dari segi perlindungan terhadap WNA korban perdagangan manusia dan pemberian kesempatan bagi WNA yang menikah dengan WNI untuk berusaha dan bekerja di Indonesia dalam rangka memenuhi kebutuhan hidupnya dan keluarganya sebagaimana dimaksud dalam pasal 61 undang-undang nomor 6 tahun 2011 tentang Keimigrasian.

Berdasarkan uraian diatas maka dapat dimpulkan bahwa Politik Hukum Keimigrasian di Indonesia saat ini adalah berdasarkan pada asas manfaat secara ekonomi dimana hanya orang yang berguna bagi bangsa dan Negara yang diizinkan untuk masuk dan tinggal di Indonesia dengan mengedepankan penghormatan terhadap HAM. Hal tersebut di aktualisasikan dalam bentuk kebijakan selektif (selective Policy) melalui Trifungsi Imigrasi. Hal ini menjadi sangat wajar, karena politik hukum suatu Negara tidak dapat dipisahkan oleh pengaruh rezim yang berkuasa. Selama masih dalam rangka untuk mencapai tujuan Negara. Saat ini memang pemerintah Indonesia sedang berkonsentrasi dalam hal peningkatan pertumbuhan ekonomi di Indonesia yang tidak dapat terlepas unsur perbaikan infrastuktur, reformasi Birokrasi dan iklim Investasi. Oleh karenanya menjadi 
sangat wajar apabila berbagai peraturan perundang-undangan yang ada harus dapat mengakomodasi kepentingan tersebut diatas.

\section{Politik Hukum Pengaturan Orang Asing di Indonesia.}

Keberadaan Undang-undang nomor 6 tahun 2011 tentang Keimigrasian diyakini dapat memberikan perlindungan terhadap HAM dan memberikan kepastian hukum terhadap orang asing di Indonesia. Namun demikian, masih terjadi conflict of Norm antara UU Keimigrasian dengan UU ketenagakerjaan. Terdapat di dalam pasal 61 Undang-undang Keimigrasian yang memberikan Kesempatan kepada orang asing yang menikah dengan WNI untuk bekerja dan berusaha untuk memenuhi kebutuhan hidup dirinya dan keluarganya. Dalam hal ini dapat di katakan bahwa segala jenis usaha dapat dilakukan oleh TKA tersebut asalkan untuk memenuhi kebutuhan hidup dirinya dan keluarganya maka diperbolehkan. Oleh karena itu mengandung unsur bertentangan dengan Politik hukum ketenagakerjaan yang selama ini telah diatakan pembatasan keberadaan TKA di Indonesia termasuk berbagai jenis usaha yang dapat jalankan oleh TKA tersebut. ${ }^{9}$

Lahirnya Undang-undang No. 6 Tahun 2011 tentang keimigrasian banyak dipengaruhi oleh berbagai aspek peraturan perundang-undangan lainnya di Indonesia maupun konvensi Internasional. Dalam hal pemberian izin tinggal terbatas misalnya harus melihat dari sisi hukum perkawinan bagi mereka yang menikah dengan WNI, begitu juga bagi mereka yang bekerja, apakah sudah sejalan dengan politik hukum ketenagakerjaan di Indonesia yang lebih mengutamakan perlindungan bagi WNI untuk memperoleh jabatan dan pekerjaan di Indonesia. Oleh karenanya kehadiran TKA yang bekerja di Indonesia dibatasi secara kuantitas jabatan yang dapat ditempati serta waktu/masa kerjanya.

Disharmonisasi dalam UU No. 6 Tahun 2011 tentang keimigrasian masih ditemukan dengan beberapa peraturan perundang-undangan yang lainnya. Sesuai yang tersebut pada pasal 61 , terjadinya sedikit pergeseran arah kebijakan yang

\footnotetext{
${ }^{9}$ Agus Sutisna, 'Pemda Tanpa Wakil Kepala Daerah'(Kompasiana, 2012) $<$ https://www.kompasiana. com/www.tisna_1965.com/pemda-tanpa-wakil-kepala-daerah_550d3b7ba333116e1c2e3a85>.
} 
selama ini sebelumnya seorang wajib WNA mmendapatkan izin tinggal untuk bekerja di Indonesia, maka harus sudah memiliki sponsor dari sebuah perusahaan yang akan memberikan mereka pekerjaan.

Terlepas dari Undang-undang Keimigrasian yang mengamanatkan reformasi birokrasi dengan mengaktualisasikan Sistem Informasi Manajemen Keimigrasian (Simkim) yang berbasis eketronik serta kemudahan bagi para investor untuk tinggal dan berinvestasi di Indonesia. Walaupun berbagai kemudahan yang bersifat pelayanan diberikan bagi WNA untuk masuk tinggal, bekerja dan berinvestasi di Indonesia, tetap diharapakan bahwa penegakkan hukum keimigrasian tidak terlupakan dan dapat berjalan secara bersama-sama sesuai dengan trifungsi Imigrasi sebagai pelayan masyarakat, penegakan hukum dan keamanan serta Fasilitator pembangunan ekonomi.

Lahirnya undang-undang nomor 6 tahun 2011 tentang Keimigrasian diyakini dapat mengatasi berbagai eskalasi kejahatan transnasional dan lebih memberikan perlindungan terhadap HAM dan memberikan kepastian hukum terhadap Orang asing yang masuk, tinggal dan melakukan aktivitas ataupun kepada sponsor mereka di Indonesia. Namun demikian bukan berarti UU tersebut tanpa kekurangan. Kita dapat lihat bahwa masih terjadi conflict of Norm antara UU Keimigrasian dengan UU ketenagakerjaan. Terlihat dalam pasal 61 Undang-undang Keimigrasian yang memberikan Kesempatan kepada orang asing yang menikah dengan WNI untuk bekerja dan berusaha untuk memenuhi kebutuhan hidup dirinya dan keluarganya.

\section{Alasan Yuridis Pengendalian Tenaga Kerja Asing Yang Bekerja di Indonesia.}

Dalam era globalisasi ekonomi, pembatasan TKA sangat diperlukan sebagai konsekuensi atas kesempatan kerja di indonesia bagi TKI sesuai penetapan pasal 27 ayat 2 UUD 1945. Keterikatan anatara hak dan kewajiban membuat praktik harus dijalankan dengan seimbang.

Sering terlihat ketimpangan antara hak dan kewajiban, terutama dalam bidang lapangan pekerjaan dan tingkat kehidupan yang layak bagi setiap warga negara. Lapangan pekerjaan dan tingkat kehidupan yang layak merupakan hal yang 
perlu diperhatikan. Pasal 27 ayat 2 UUD 1945 menjelaskan bahwa "Tiap-tiap warga negara berhak atas pekerjaan dan penghidupan yang layak bagi kemanusiaan“. Secara garis besar dapat dijelaskan bahwa pekerjaan dan tingkat kehidupan yang layak merupakan hak untuk setiap warga negara sebagai salah satu tanda adanya perikemanusiaan. Lapangan pekerjaan merupakan sarana yang dibutuhkan guna menghasilkan pendapatan yang akan digunakan dalam pemenuhan kehidupan yang layak. Penghidupan yang layak diartikan sebagai kemampuan dalam melakukan pemenuhan kebutuhan dasa, seperti : pangan, sandang, dan papan.

Ketidak harmonisan antara hak dan kewajiban, terlebih dalam bidang pemenuhan lapangan pekerjaan dan tingkat kehidupan yang layak bagi setiap warga negara yang berada di Indonesia menimbulkan permasalahan tersendiri. Lapangan pekerjaan dan tingkat kehidupan yang layak merupakan hal yang perlu diperhatikan dan dijadikan prioritas dalam setiap pembuatan arah kebijakan yang berkaitan dengan ketenagakerjaan. Pegendalian TKA yang bekerja di Indonesia merupakan salah satu tujuan untuk melindungi warga negara Indonesia dari kehilangan pekerjaannya dikarenakan banyaknya TKA yang datang untuk bekerja di Indonesia. Hal ini merupakan implementasi dari pemenuhan hak asasi manusia termasuk dalam hak asasi untuk bekerja secara bebas di negaranya sendiri. Dan termasuk juga bentuk pemenuhan hak bagi warga negara asing untuk bisa bekerja di Indonesia meskipun dengan pembatasan-pembatasn tertentu. Adapun politik hukumnya adalah warga negara asing boleh bekerja di Indonesia tetapi tidak boleh mengurangi hak warga negara Indonesia itu sendiri untuk mendapatkan pekerjaan yang layak di negaranya sendiri. Oleh karena itu keberadaan TKA tersebut perlu di kendalikan dengan dibatasi oleh aturan-aturan yang ada dan hanya bidang pekerjaan tertentu saja yang diperbolehkan. Sehingga diperlukan aturan perundang-undangan tentang pengendalian TKA yang bekerja di Indonesia.

Pada prinsipnya orang asing bahkan yang merupakan penduduk Indonesia mempunyai hak dan kewajiban yang berbeda dengan hak dan kewajiban warga negara Indonesia. Terhadap orang asing dikenakan pembatasan-pembatasan tertentu, khususnya yang menyangkut masalah hak.Berdasarkan ketentuan Undang-Undang 
Keimigrasian, setiap orang dapat dibatasi ruang geraknya bahkan dapat dideportasi atau di persona non grata-kan atau diserahkan kepada negara lain, terutama apabila melakukan tindak pidana. Keadaan ini tentunya berbeda dengan status sebagai warga negara Indonesia (yang mempunyai hak keluar masuk Indonesia) tetapi untuk orang asing hanya mempunyai hak keluar wilayah Indonesia. Di samping itu, setiap orang asing harus mendaftarkan diri sesuai dengan peraturan perundangan yang berlaku Di bidang politik, orang asing tidak diperkenankan untuk turut campur dalam politik dalam negeri Indonesia.

\section{Urgensi Pengendalian Tenaga Kerja Asing Yang Bekerja Di Indonesia}

Adanya konsep negara dan kedaulatan atas wilayah tertentu, maka dalam melakukan perjalanan antarnegara digunakan passport yang berarti izin melewati pelabuhan atau pintu masuk bandar udara dan perbatasan negara. Paspor ini biasanya memuat identitas pemegang dan negara yang mengeluarkan adapun Negara yang mengeluarkan berkewajiban melindungi di manapun pemegang tersebut dimanapun keberadaannya. Dalam upaya menyeleksi dan memantau dalam hal ini melakukan pengawasan terhadap orang asing yang masuk dalam suatu negara dibutuhkan visa (visum laporan atau keterangan telah diperiksa) yang telah dibubuhi stempel sah dari pejabat yang berwenang.

Pasal 46 ayat 1 UUK menentukan bahwa TKA dilarang menduduki jabatanjabatan tertentu. Dalam Lampiran Keputusan Menteri Tenaga Kerja dan Transmigrasi Republik Indonesia Nomor 40 Tahun 2012 tentang Jabatan-Jabatan Tertentu yang Dilarang Diduduki TKA lebih khusus lagi menyebutkan jabatan-jabatan apa saja yang dilarang untuk di jabat oleh TKA di Indonesia. Jabatan-jabatan yang boleh di tempati oleh TKA digolongkan dalam beberapa kelompok berdasarkan Keputusan Menteri Tenaga Kerja Dan Transmigrasi Republik Indonesia.

BerlakunyaUndang-UndangNomor6 Tahun 2011 tentang keimigrasianmerupakan sarana penegakan hukum terhadap pelaku tindak pidana keimigrasian. Undang-undang ini mengatur beberapa kemungkinan kejahatan-kejahatan yang dilakukan baik oleh WNI dan WNA serta perusahaan sebagai sponsor keberadaan dan kegiatannya. 
Mekanisme penegakan hukum Secara operasional di bidang keimigrasian dilakukan dengan dua cara, yakni dengan mekanisme di luar peradilan dan mekanisme di dalam peradilan. Adapun mekanisme di luar peradilan yang disebut dengan tindakan administratif keimigrasian dan melalui mekanisme peradilan yang disebut proses penyidikan. Sesuai yang diatur dalam Pasal 1 angka 31 UndangUndang Keimigrasian. Menurut Kitab Undang-Undang Hukum Acara Pidana adapun Penyidikan sesuai yang tersebut dalam Pasal 1 angka 2. Hukum merupakan suatu aturan yang muncul seiring dengan adanya manusia yang hidup berkelompok atau bermasyarakat (zoon politicon). Pada hakikatnya dibuat oleh manusia itu dan untuk ditaati oleh manusia itu sendiri. Tentunya hukum diciptakan untuk mengatur tata tertib kehidupan bermasyarakat, berbangsa, dan bernegara.

Asas kepastian hukum merupakan salah satu materi muatan dari terbentuknya peraturan perundang-undangan. Asas kepastian hukum mengisyaratkan bahwa setiap peraturan harus dirumuskan dengan jelas dan tepat serta perubahannya harus memperhitungkan kepentingan orang yang mengenai peralihan. Di dalam UU No. 6 Tahun 2011 tentang Keimigrasian masih ditemukan beberapa pasal yang belum dapat memberikan kepastian secara hukum. Sebagai contoh di dalam Pasal 38 dikatakan, bahwa visa kunjungan diberikan kepada orang asing yang akan melakukan perjalanan ke wilayah Indonesia dalam rangka kunjungan tugas pemerintahan, pendidikan, kerja sosial budaya, pariwisata, bisnis, keluarga, jurnalistik, atau singgah untuk meneruskan peralanan negara lain. Di dalam penjelasan angka 17 dikatakan bahwa visa kunjungan dapat diberikan untuk maksud dan tujuan melaku kan audit, kendali mutu produksi, atau inspeksi pada cabang perusahaan di Indonesia. Sedangkan angka 18 disebutkan visa kunjungan dapat diberikan kepada calon tenaga kerja asing dalam uji coba kemampuan bekerja. Jika dilihat dalam Pasal 39 tentang pemberian visa tinggal terbatas dikaitkan dengan bunyi penjelasannya mengenai maksud pemberian izin tinggal terbatas untuk g dikatakan bahwa visa tinggal terbatas diberikan kepada orang asing untuk melakukan inspeksi atau audit pada cabang perusahaan di Indonesia, sedangkan dalam huruf n disebutkan bahwa visa tinggal terbatas untuk calon di tenaga kerja 
asing yang akan bekerja dalam rangka uji coba keahlian. Hal ini menimbulkan ketidakpastian hukum karena kedua jenis visa tidak memiliki an pembedaan yang jelas antara kegunaan visa kunjungan dan kegunaan visa antara tinggal terbatas.

\section{Kesimpulan}

Berdasarkan pembahasan yang telah diuraikan dalam bab-bab sebelumnya maka dapat dirumuskan kesimpulan berupa Ratio legis pengendalian TKA yang bekerja di Indonesia didasarkan pada Pasal 27 ayat 2 UUD 1945. Pegendalian TKI yang bekerja di Indonesia merupakan salah satu tujuan untuk melindungi hak WNI dari kehilangan pekerjaannya dikarenakan banyaknya TKA yang datang untuk bekerja di Indonesia semakin hari semakin bertambah banyak. Pengendalian tersebut merupakan implementasi dari pemenuhan HAM termasuk dalam hak asasi untuk bekerja secara bebas di negaranya sendiri. Adapun politik hukumnya adalah WNA boleh bekerja di Indonesia tetapi tidak boleh mengurangi hak WNI itu sendiri untuk mendapatkan pekerjaan yang layak di negaranya sendiri oleh karena itu diperlukan aturan perundang-undangan tentang pengendalian TKA yang bekerja di Indonesia.

Urgensi pengendalian TKA yang bekerja di Indonesia merupakan suatu bentuk dari tanggung jawab negara dalam melindungi warga negaranya sesuai dengan Pasal 28 I ayat 4. Terkait dengan penggunaan TKA di Indonesia harus dibatasi baik dalam jumlah maupun bidang-bidang yang dapat diduduki oleh TKA dengan tujuan agar kehadiran TKA di Indonesia bukanlah dianggap sebagai ancaman yang cukup serius bagi TKI, justru kehadiran mereka sebagai pemicu atau penyemangat bagi TKI untuk lebih professional dan selalu menambah kemampuan dirinya agar dapat bersaing baik antara sesama TKI maupun dengan TKA. Selain harus mentaati ketentuan tentang jabatan, juga harus memperhatikan standar kompetansi yang berlaku sehingga pengendalian TKA juga diperlukan untuk mempermudah adanya pengawasan terhadap TKA yang datang untuk bekerja di Indonesia agar tidak terjadi penyalahgunaan izin yang sadah diberikan. Segala bentuk pelanggaran bisa di kenakan sanksi sesuai aturan yang berlaku. 
Berdasarkan kesimpulan yang telah dirumuskan maka saran yang dianggap perlu berupa; Diperlukannya penjelesan ratio legis pengaturan pengendalian tenaga kerja asing yang bekerja di Indonesia yang lebih kongkrit agar warga negara Indonesia semakin terjamin hak-haknya untuk bekerja di negaranya sendiri sebelum mendatangkan tenaga kerja asing. Untuk mengantisipasi hal tersebut diharapkan ada kelengkapan peraturan yang mengatur persyaratan tenaga kerja asing, serta pengamanan penggunaan tenaga kerja asing. Peraturan tersebut harus mengatur aspek-aspek dasar dan bentuk peraturan yang mengatur tidak hanya di tingkat Menteri, dengan tujuan penggunaan tenaga kerja asing secara selektif dengan tetap memprioritaskan tenaga kerja Indonesia. Diperlukannya pengaturan tentang penegakan hukum pengendalian tenaga kerja asing dalam bidang perizinan yang lebih ketat. Hal ini guna untuk meminimalisasi terjadinya pelanggaran-pelanggaran yang dilakukan oleh perusahaan peruntukan izin yang di dapat. Sehingga mudah untuk bisa dilakukan pengawasan. Memperketat dengan menerbitkan peraturan tentang jabatan-jabatan yang dapat diduduki oleh TKA sehingga tenaga kerja Indonesia akan tetap dapat terserap dengan baik.

\section{Daftar Bacaan}

\section{Buku}

Bernard L, Politik Hukum (Genta Publising 2011).

Charles Christian, Hukum Keimigrasian Bagi Orang Asing Di Indonesia (Sinar Grafika 2015).

Jazim Hamidi dan Charles Christian, Hukum Keimigrasian Bagi Orang Asing Di Indonesia (Sinar Grafika 2015).

Mahfud MD, Politik Hukum Di Indonesia, (Rajawali Pers 2010).

Peter Mamud Marzuki, Penelitian Hukum (Kencana 2006).

Philipus M. Hadjon, Pengantar Hukum Admistrasi Indonesia (Gadjah Mada University Press 2008). 


\section{Jurnal}

Budi S.P. Nababan, 'Pembentukan Peraturan Daerah Tentang Retribusi Perpanjangan Izin Mempekerjakan Tenaga Kerja Asing Sebagai Persiapan Menghadapi Masyarakat Ekonomi ASEAN 2015' (2014) 3 Rechvinding.

\section{Website}

Agus Sutisna, 'Pemda Tanpa Wakil Kepala Daerah' (Kompasiana, 2012) <https:// www.kompasiana.com/www.tisna_1965.com/pemda-tanpa-wakil-kepala-da erah_550d3b7ba333116e1c2e3a85>.

\section{Perundang-undangan}

Panduan Pemasyarakatan Undang-Undang Dasar Republik Indonesia Tahun 1945 (Sesuai dengnan Urutan Bab, Pasal dan ayat) 2010.

HOW TO CITE: Galih Arya Prathama, 'Eksistensi Pajak Daerah Sebagai Wujud Pelaksanaan Otonomi Daerah Dalam Kerangka Good Financial Governance' (2018) Vol. 1 No. 2 Media Iuris. 